\title{
A Nexus of Progression of Chronic Kidney Disease: Charcoal, Tryptophan and Profibrotic Cytokines
}

\author{
Gerald Schulman \\ Vanderbilt University School of Medicine, Vanderbilt University Medical Center, Nashville, Tenn., USA
}

\section{Key Words}

Indoxyl sulfate $\cdot$ Uremic toxins $\cdot$ AST-120

\begin{abstract}
Fibrosis plays a role in the pathogenesis of progressive chronic kidney disease (CKD). The inhibition of the reninangiotensin system, which promotes fibrosis, has become the standard of care in the treatment of patients with CKD. A novel charcoal compound, AST-120, has been used for over a decade in Japan to prevent progression of CKD. It is thought that the oral administration of AST-120 blocks the intestinal absorption of tryptophanderived indole. This prevents the hepatic conversion of indole to indoxyl sulfate (IS). IS has been shown to stimulate the production of profibrotic cytokines such as transforming growth factor-beta. AST-120 lowers IS in a dose dependent fashion and does not change the creatinine appearance rate in the urine. Enteric capsules containing Bifidobacterium longum have been shown to prevent progression of CKD in a preliminary study. These findings suggest that prospective clinical trials be undertaken to determine if these other potential methods of inhibiting fibrosis are useful in slowing progressive CKD.
\end{abstract}

\section{KARGER}

Fax +4161306 1234 E-Mail karger@karger.ch www.karger.com
The incidence of end-stage renal disease (ESRD) in the United States (US) has increased annually over the past decade - a development with important implications for individual patients and caregivers, as well as for society. The nephroprotective effects of captopril, an angiotensinconverting enzyme inhibitor, have been demonstrated in a well-designed prospective, randomized clinical study [1]; captopril is available in the US for the treatment of type 1 diabetic nephropathy. Ramipril, another angiotensin-converting enzyme inhibitor, has been shown to slow the progression of chronic kidney disease (CKD) [2], and the nephroprotective effects of losartan and irbesartan (angiotensin II receptor blockers) have been demonstrated in long-term, large-scale studies [3-5]. These agents have now been approved for the treatment of type 2 diabetic nephropathy.

However, even with these available treatments, a substantial number of patients still progress to ESRD. New agents capable of altering the rate of decline in renal function through novel pharmacological mechanisms offer a potentially meaningful expansion in the number of treatment options. To augment the number of treatment options currently available, new agents operating via novel mechanisms of action are needed to slow renal deterioration in patients with CKD. 
Fig. 1. The Japanese experience. Slowing the progression of CKD with administration of AST-120. 1/s-Cr slope before and after the initiation of kremezin administration. Number of patients $=416 . p=0.0001$, paired U test.

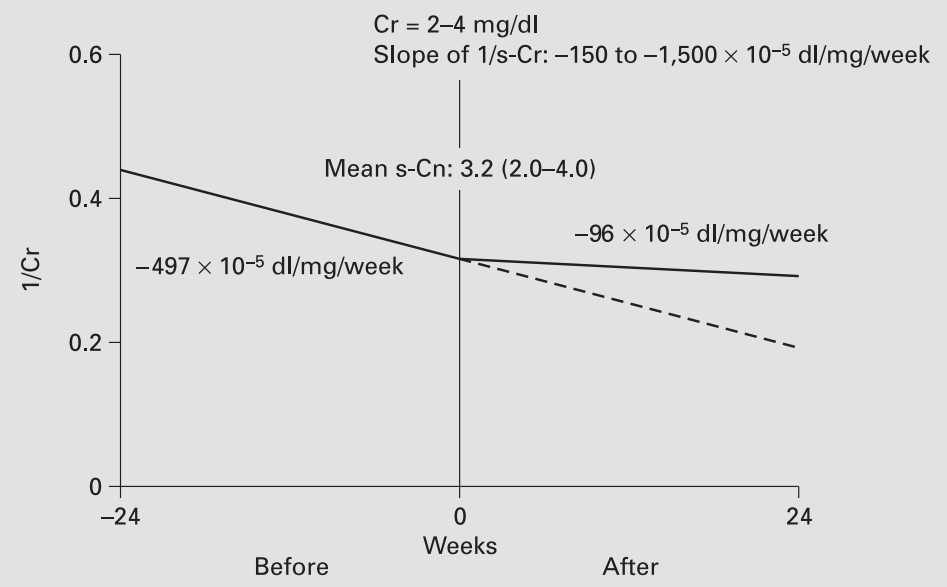

Indoxyl sulfate (IS) is one of many uremic toxins [6]. Serum IS levels are elevated in patients with CKD and appear to correlate with disease progression. Administration of IS to nephrectomized rats resulted in decreased renal function and increased glomerular sclerosis in the remnant kidney [7]. Furthermore, IS stimulated the transcription of genes related to renal fibrosis, such as transforming growth factor-beta 1 and tissue inhibitor of metalloproteinases 1 , and pro-alpha 1 collagen has been observed $[8,9]$. Uremic toxins, including IS, may induce free radical production by renal tubular cells and activate nuclear factor- $\kappa \mathrm{B}$ which, in turn, upregulates plasminogen activator inhibitor 1 expression [10]. The induction of nephrotoxicity by IS may be mediated by the organic anion transporters such as OAT1 and OAT3 [11]. In vivo synthesis of IS begins with enterobacterium-mediated conversion of dietary tryptophan to indole in the gastrointestinal tract. Following enteric absorption, hepatic hydroxylation and sulfation of indole results in the formation of IS. Patients with normal renal function have serum IS levels approaching $0 \mathrm{mg} / \mathrm{dl}$, whereas values progressively increase in patients with renal compromise, generally exceeding $0.8-1.0 \mathrm{mg} / \mathrm{dl}$ in those with serum creatinine $\geq 3.0 \mathrm{mg} / \mathrm{dl}[7]$.

The oral adsorbent AST-120 has a superior adsorption ability for certain small molecular weight organic compounds known to accumulate in CKD patients. In uremic rats and patients with $\mathrm{CKD}$, the oral administration of AST-120 has reduced the elevated pretreatment levels of serum IS $[12,13]$. The mechanism of action of AST-120 may be related to its ability to absorb enteric indole, resulting in a lowering of elevated serum IS levels. The administration of AST-120 has been shown to slow the rate of progression of CKD (fig. 1).

AST-120 also absorbs many additional substances that are putative toxins. These substances can have an impact on the progression of CKD. Nevertheless, AST-120 has clearly been shown to prevent glomerular hypertrophy, interstitial fibrosis, proteinuria, and worsening renal failure. This study reports effect of three doses of AST-120 $(0.9,2.1$, or $3.0 \mathrm{~g}$ three times a day) compared with placebo on the change from baseline in serum IS levels as a surrogate endpoint for a potential nephroprotective effect. This study also evaluated the potential for AST-120 to affect serum creatinine levels independent of its potential effect on renal function, e.g., as a consequence of creatinine adsorption in the gut lumen altering urine creatinine appearance in 24-hour urine creatinine $\left(\mathrm{U}_{\text {creatinine }} \mathrm{V}\right)$.

\section{Study Population}

A total of 164 patients were randomized to receive at least one dose of the study drug: $41(25.0 \%)$ in the 9.0-gram AST-120 treatment group, $41(25.0 \%)$ in the 6.3-gram AST-120 treatment group, $40(24.4 \%)$ in the 2.7-gram AST-120 treatment group, and $42(25.6 \%)$ in the placebo treatment group.

Patients ranged in age from 25 to 88 years, with a mean age of 64.6 years. The majority of these patients were 
Table 1. Demographic and baseline characteristics

\begin{tabular}{|c|c|c|c|c|}
\hline \multirow[t]{2}{*}{ Parameter } & \multicolumn{4}{|c|}{ Treatment group } \\
\hline & $\begin{array}{l}9.0 \mathrm{~g} \text { AST }-120 \\
(\mathrm{n}=39)\end{array}$ & $\begin{array}{l}6.3 \mathrm{~g} \text { AST }-120 \\
(\mathrm{n}=40)\end{array}$ & $\begin{array}{l}2.7 \text { g AST-120 } \\
(\mathrm{n}=39)\end{array}$ & $\begin{array}{l}\text { placebo } \\
(n=39)\end{array}$ \\
\hline \multicolumn{5}{|l|}{ Age, years } \\
\hline $\mathrm{n}$ & 39 & 40 & 39 & 39 \\
\hline Mean $\pm \mathrm{SD}$ & $69.3 \pm 13.93$ & $66.3 \pm 10.24$ & $59.6 \pm 13.83$ & $63.1 \pm 12.94$ \\
\hline Median & 71 & 66.5 & 59 & 65 \\
\hline Minimum/maximum & $40 / 88$ & $37 / 86$ & $29 / 81$ & $25 / 84$ \\
\hline \multicolumn{5}{|l|}{ Gender } \\
\hline Male & $30(76.9)$ & $22(55.0)$ & $30(76.9)$ & $25(64.1)$ \\
\hline Female & $9(23.1)$ & $18(45.0)$ & $9(23.1)$ & $14(35.9)$ \\
\hline \multicolumn{5}{|l|}{ Race } \\
\hline Caucasian & $0(76.9)$ & $29(72.5)$ & $24(61.5)$ & $22(56.4)$ \\
\hline Black & $3(7.7)$ & $9(22.5)$ & $9(23.1)$ & $11(28.2)$ \\
\hline Asian & $1(2.6)$ & $1(2.5)$ & $3(7.7)$ & 0 \\
\hline Hispanic & $5(12.8)$ & $1(2.5)$ & $2(5.1)$ & $6(15.4)$ \\
\hline American Indian & 0 & 0 & $1(2.6)$ & 0 \\
\hline Other & 0 & 0 & 0 & 0 \\
\hline \multicolumn{5}{|l|}{ Height, $\mathrm{cm}$} \\
\hline $\mathrm{n}$ & 39 & 39 & 36 & 38 \\
\hline Mean $\pm \mathrm{SD}$ & $172.2 \pm 10.77$ & $170.1 \pm 10.04$ & $169.6 \pm 11.21$ & $170.3 \pm 9.58$ \\
\hline Median & 171 & 170.2 & 170.1 & 170.2 \\
\hline Minimum/maximum & $147 / 198$ & $152 / 185$ & $147 / 191$ & $155 / 185$ \\
\hline \multicolumn{5}{|l|}{ Weight, $\mathrm{kg}$} \\
\hline $\mathrm{n}$ & 39 & 40 & 39 & 39 \\
\hline Mean $\pm \mathrm{SD}$ & $85.6 \pm 21.07$ & $93.2 \pm 17.95$ & $94.6 \pm 23.79$ & $94.8 \pm 20.99$ \\
\hline Median & 83 & 92.4 & 90.9 & 91.9 \\
\hline Minimum/maximum & $44 / 148$ & $49 / 134$ & $47 / 144$ & $60 / 146$ \\
\hline \multicolumn{5}{|l|}{ Type of CKD } \\
\hline Diabetic nephropathy & $22(56.4)$ & $24(60.0)$ & $22(56.4)$ & $17(43.6)$ \\
\hline Non-diabetic nephropathy & $17(43.6)$ & $16(40.0)$ & $17(43.6)$ & $22(56.4)$ \\
\hline
\end{tabular}

Figures in parentheses are percentages.

Caucasian (66.9\%) and male (68.2\%). The average duration of therapy was 84 days. Demographic and baseline characteristics showed homogeneity between treatment groups for gender, race, height, weight, and type of CKD (table 1).

\section{Efficacy Evaluations}

\section{Primary Endpoints}

Figure 2 shows the mean changes in serum IS levels from baseline for the intent-to-treat population at weeks 8 and 12 . For the primary analysis, the mean changes from baseline in serum IS levels for the 9.0- and 6.3-gram AST-120 treatment groups showed statistically significant decreases at week 12 (for both active treatment groups, $p \leq 0.002$ and $p<0.001$ for the paired $t$ test and signed rank test within treatment group analyses, respectively) (table 2).

For the secondary analysis, mean changes from baseline in serum IS levels for the 9.0- and 6.3-gram AST-120 treatment groups showed dose-related statistically significant decreases when compared with placebo at week 12 ( $p \leq 0.03$ for the ANCOVA model and Mann-Whitney test for both treatment groups). 

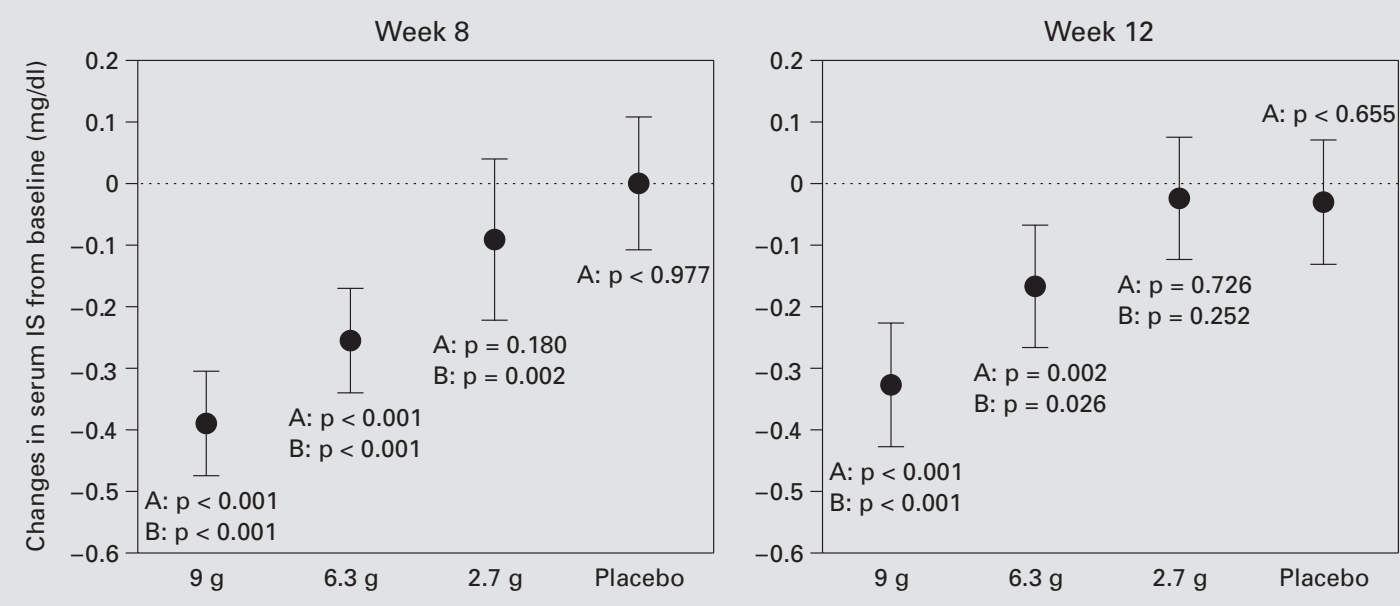

Fig. 2. Mean changes in serum IS values from baseline. The mean point estimates with $95 \%$ confidence intervals of the changes in the serum IS levels from baseline to weeks 8 and 12 are presented. A = Paired t test with treatment group; B = ANCOVA model (AST-120 vs. placebo).

Table 2. Changes in serum IS (mg/dl) from baseline to week 12

\begin{tabular}{|c|c|c|c|c|}
\hline \multirow[t]{2}{*}{ Visit } & \multicolumn{4}{|c|}{ Treatment group } \\
\hline & $\begin{array}{l}9.0 \text { g AST }-120 \\
(\mathrm{n}=38)\end{array}$ & $\begin{array}{l}6.3 \mathrm{~g} \text { AST }-120 \\
(\mathrm{n}=39)\end{array}$ & $\begin{array}{l}2.7 \text { g AST- } 120 \\
(\mathrm{n}=39)\end{array}$ & $\begin{array}{l}\text { placebo } \\
(\mathrm{n}=38)\end{array}$ \\
\hline \multicolumn{5}{|l|}{ Baseline values 1} \\
\hline Mean $\pm \mathrm{SD}$ & $0.84 \pm 0.407$ & $0.85 \pm 0.386$ & $0.78 \pm 0.332$ & $0.98 \pm 0.364$ \\
\hline \multicolumn{5}{|l|}{ Change from baseline to week 12} \\
\hline $\mathrm{n}$ & 38 & 39 & 39 & 38 \\
\hline Mean $\pm \mathrm{SD}$ & $-0.330 \pm 0.298$ & $-0.171 \pm 0.321$ & $-0.020 \pm 0.359$ & $-0.027 \pm 0.371$ \\
\hline Median & -0.265 & -0.180 & -0.040 & -0.015 \\
\hline Minimum/maximum & $-0.88 / 0.42$ & $-0.75 / 1.07$ & $-0.85 / 1.36$ & $-1.20 / 0.98$ \\
\hline \multicolumn{5}{|l|}{ LS treatment difference } \\
\hline Mean $\pm \mathrm{SE}^{2}$ & $-0.329 \pm 0.0771$ & $-0.171 \pm 0.0761$ & $-0.089 \pm 0.0772$ & \\
\hline $95 \% \mathrm{CI}^{2}$ & -0.48 to -0.18 & -0.32 to -0.02 & -0.24 to 0.06 & \\
\hline \multicolumn{5}{|l|}{ pvalue } \\
\hline Paired t test within treatment group & $<0.001$ & 0.002 & 0.726 & 0.655 \\
\hline Signed rank test within treatment group & $<0.001$ & $<0.001$ & 0.279 & 0.574 \\
\hline ANCOVA model $^{2}$ & $<0.001$ & 0.026 & 0.252 & \\
\hline Mann-Whitney test ${ }^{3}$ & $<0.001$ & 0.010 & 0.632 & \\
\hline
\end{tabular}

The last non-missing observed post-baseline value was used if a post-baseline value was missing. If a patient terminated early, the value for week 12/early termination visit was used for each following scheduled visit(s). $\mathrm{LS}=$ Least square; $\mathrm{SE}=$ standard error; $\mathrm{Cl}=$ confidence interval.

${ }^{1}$ Baseline value was week 0 value, or screening value if week 0 value was missing.

${ }^{2}$ LS mean treatment difference, SE, 95\% CI, and p value for treatment difference (AST-120 vs. placebo) were based on the ANCOVA model, with treatment and center as factors, and baseline measurement as covariate.

${ }^{3} \mathrm{p}$ value (AST-120 vs. placebo) was based on Mann-Whitney test with treatment as factor. 


\section{Secondary Endpoints}

A number of secondary efficacy variables were evaluated. Over the 12-week study period, patients treated with AST-120 showed no consistent or dose-related changes in serum creatinine, reciprocal of serum creatinine, creatinine clearance, or urine protein. The mean change from baseline in $\mathrm{U}_{\text {creatinine }} \mathrm{V}$ in the 6.3-gram AST120 treatment group showed a statistically significant decrease $(-119.48)$ at week 12 for the paired t test within treatment group analyses $(p=0.047)$. However, this was not evident in other dose groups; notably, $\mathrm{U}_{\text {creatinine }} \mathrm{V}$ showed a slight increase in the 9.0-gram AST-120 treatment group.

Serum IS was progressively reduced by increasing doses of AST-120. At week 12, patients randomized to the 9.0-gram AST-120 treatment group showed a 39.3\% decrease in the change from baseline in serum IS levels. A significant decrease of $21.1 \%$ in the change from baseline to week 12 was also observed in patients who were treated with $6.3 \mathrm{~g}$ AST-120. The 2.7-gram AST-120 treatment group and the placebo treatment group showed little change, with decreases of 2.6 and $2.8 \%$, respectively.

In the Japanese study performed by Niwa et al. [13], 22 patients who were treated with 6.0 g AST-120 per day showed a decrease of $38.5 \%$ in serum IS from baseline to 1 month (from a mean value of 2.52 to $1.55 \mathrm{mg} / \mathrm{dl}$ ). Furthermore, patients treated with AST-120 (6.0 g/day) and on a low protein diet $(0.6 \mathrm{~g} / \mathrm{kg} /$ day $)$ showed a $34.0 \%$ decrease in serum IS (from a mean value of 1.62 to $1.07 \mathrm{mg} / \mathrm{dl}$ ) in $13 \mathrm{CKD}$ patients in Japan for a 6-month period [14]. Since the 9.0-gram AST-120 treatment group showed almost the same decrease in the US patients as the Japanese experience, this dosage may be adequate for the US patients.

Indole is synthesized in the intestine as a metabolite of tryptophan by intestinal bacteria and absorbed from the intestine into blood. IS is then synthesized from indole to indoxyl in the liver. Orally administered AST120 adsorbs indole in the intestine and is excreted into feces, thereby inhibiting the synthesis of IS from indole in the liver [12]. The amount of tryptophan is in proportion to the ingested food, and the amount of food may be in proportion to the body weight. The mean weight of patients in this study was approximately $90 \mathrm{~kg}$ and the mean weight of patients in the Japanese phase III study was approximately $55 \mathrm{~kg}$. Since the amount of adsorption for indole is in proportion to the amount of orally administered AST-120, the daily dose of $9.0 \mathrm{~g}$ AST-120 may be a reasonable amount for the US population.
Only $14(9.1 \%)$ patients in the four treatment groups required dialysis (initiation of hemodialysis, or serum creatinine $>8.0 \mathrm{mg} / \mathrm{dl}$ in non-diabetic patients or $>6.0 \mathrm{mg} / \mathrm{dl}$ in diabetic patients) and attained the composite endpoint. There were no statistical differences among the four treatment groups. In addition, no patients in any of the four treatment groups attained doubling of serum creatinine or died. It is likely that the findings of the current study are due to the short study period of only 12 weeks. Thus, in order to clarify the effects of AST-120 on such a composite endpoint, a long-term larger study will be needed.

For the possible reasons of a relatively short study period and no inclusion criterion of progressive CKD, patients treated with AST-120 showed no consistent or dose-related changes in serum creatinine, reciprocal of serum creatinine, creatinine clearance, or urine protein. $\mathrm{U}_{\text {creatinine }} \mathrm{V}$ changed little, suggesting that there was no meaningful transluminal gastrointestinal adsorption of creatinine and that changes in serum creatinine in patients treated with AST-120 would be indicative of changes in renal function. The results of this study support the notion of using a composite endpoint of a doubling of serum creatinine, transplant, or initiation of hemodialysis as a hard endpoint for nephroprotective effect in a future therapeutic confirmatory study. Indeed, similar endpoints have been accepted in other studies that have examined therapeutic interventions in slowing the progression of CKD [3, 4].

In the present study, AST-120 was taken an hour after concomitant medications; extensive experience and clinical data suggest little chance for pharmacokinetic drugdrug interactions. To confirm the appropriate interval between concomitant medications and AST-120, another clinical pharmacology study was performed in parallel with this study.

AST-120 can safely lower the levels of serum IS, a uremic toxin, in patients with CKD. A therapeutic confirmatory study is planned to determine if this effect can attenuate the progression of CKD. This drug may also be useful in preserving residual renal function in patients who have reached ESRD.

Other strategies are being developed to prevent progression of CKD. In a preliminary study, an enteric capsule containing the bacterium Bifidobacterium longum has been shown to slow progression of advanced CKD [15].

Blood Purif 2006;24:143-148 


\section{References}

$\checkmark 1$ Lewis EJ, Hunsicker LG, Bain RP, Rohde RD: The effect of angiotensin-converting-enzyme inhibition on diabetic nephropathy. N Engl J Med 1993;329:1456-1462.

-2 Ruggenenti P, Perna A, Gherardi G, Garini G, Zoccali C, Salvadori M, Scolari F, Schena FP, Remuzzi G: Renoprotective properties of ACE inhibition in non-diabetic nephropathies with non-nephrotic proteinuria. Lancet 1999;354: 359-364.

-3 Brenner BM, Cooper ME, de Zeeuw D, Keane WF, Mitch WE, Parving HH, Remuzzi G, Snapinn SM, Zhang Z, Shahinfar S, RENAAL Study Investigators: Effects of losartan on renal and cardiovascular outcomes in patients with type 2 diabetes and nephropathy. N Engl J Med 2001;345:861-869.

-4 Lewis EJ, Hunsicker LG, Clarke WR, Berl T, Pohl MA, Lewis JB, Ritz E, Atkins RC, Rohde R, Raz I, Collaborative Study Group: Renoprotective effect of the angiotensin-receptor antagonist irbesartan in patients with nephropathy due to type 2 diabetes. N Engl J Med 2001; 345:851-860.

$\checkmark 5$ Parving $\mathrm{HH}$, Lehnert H, Brochner-Mortensen J, Gomis R, Andersen S, Arner P, Irbesartan in Patients with Type 2 Diabetes and Microalbuminuria Study Group: The effect of irbesartan on the development of diabetic nephropathy in patients with type 2 diabetes. N Engl J Med 2001;345:870-878.
-6 Vanholder R, De Smet R, Glorieux G, Argiles A, Baurmeister U, Brunet P, Clark W, Cohen G, De Deyn PP, Deppisch R, DescampsLatscha B, Henle T, Jorres A, Lemke HD, Massy ZA, Passlick-Deetjen J, Rodriguez M, Stegmayr B, Stenvinkel P, Tetta C, Wanner C, Zidek W, European Uremic Toxin Work Group (EUTox): Review on uremic toxins: classification, concentration, and interindividual variability. Kidney Int 2003;63:19341943.

7 Niwa T, Ise M: Indoxyl sulfate, a circulating uremic toxin, stimulates the progression of glomerular sclerosis. J Lab Clin Med 1994;124: 96-104.

8 Miyazaki T, Ise M, Seo H, Niwa T: Indoxyl sulfate increases the gene expression of TGFbeta 1, TIMP-1 and pro-alpha 1(I) collagen in uremic rat kidneys. Kidney Int 1997;52:S15S22.

$>9$ Miyazaki T, Aoyama I, Ise M, Seo H, Niwa T: An oral sorbent reduces overload of indoxyl sulfate and gene expression of TGF-beta1 in uremic rat kidneys. Nephrol Dial Transplant 2000;15:1773-1781.

10 Motojima M, Hosokawa A, Yamato H, Muraki T, Yoshioka T: Uremic toxins of organic anions up-regulate PAI-1 expression by induction of NF-kappaB and free radical in proximal tubular cells. Kidney Int 2003;63:1671-1680.
11 Enomoto A, Takeda M, Tojo A, Sekine T, Cha SH, Khamdang S, Takayama F, Aoyama I, Nakamura S, Endou H, Niwa T: Role of organic anion transporters in the tubular transport of indoxyl sulfate and the induction of its nephrotoxicity. J Am Soc Nephrol 2002;13:17111720.

12 Niwa T, Yazawa T, Ise M, Sugano M, Kodama T, Uehara Y, Maeda K: Inhibitory effect of oral sorbent on accumulation of albumin-bound indoxyl sulfate in serum of experimental uremic rats. Nephron 1991;57:84-88.

13 Niwa T, Tsukushi S, Ise M, Miyazaki T, Tsubakihara Y, Owada A, Shiigai T: Indoxyl sulfate and progression of renal failure: effects of a low-protein diet and oral sorbent on indoxyl sulfate production in uremic rats and undialyzed uremic patients. Miner Electrolyte Metab 1997;23:179-184.

14 Owada A, Nakao M, Koike J, Ujiie K, Tomita K, Shiigai T: Effects of oral adsorbent AST-120 on the progression of chronic renal failure: a randomized controlled study. Kidney Int 1997; 52(suppl 63):S188-S190.

15 Ando Y, Miyata Y, Tanba K, Saito O, Muto S, Kurosu M, Homma S, Kasano E, AsanoY: Effect of oral intake of an enteric capsule preparation containg Bifidobacterium longum on the progression of chronic renal failure. Nippon Jinzo Gakkai Shi 2003;45:759-764. 